\title{
A STUDY OF METABOLIC FACTORS INVOLVED IN THE INTRACELLULAR GERMINATION OF CLOSTRIDIUM BOTULINUM SPORES AFTER PHAGOCYTOSIS
}

\author{
J. B. SUZUKI* AND N. GreCZ \\ Department of Biology, Illinois Institute of Technology, \\ Chicago, Illinois 60616, USA
}

THE chemical environment within the metabolically active leucocyte during the phagocytic act is conducive to intracellular spore germination. This leucocyte-induced germination of Clostridium botulinum type A spores has been studied in various in-vitro systems after Booth, Suzuki and Grecz (1971a) reported that heat-resistant spores of this organism are converted to heatsensitive germinated spores and vegetative cells in the peritoneal cavity after they have been injected intraperitoneally (IP) into mice.

These workers used new staining techniques (Booth, Suzuki and Grecz, 1971b) to demonstrate phagocytosis by leucocytes in vivo and in vitro and to show subsequent germination of the spores within the leucocyte. Furthermore, Suzuki, Booth and Grecz (1970) recently found that $\mathrm{Cl}$. botulinum spores must be actively phagocytosed to release toxin. The production of an equivalent ionic environment or exposure of the spores to leucocyte cytoplasmic extracts did not, by themselves, induce spore germination or toxin release. Studies involving the implantation of Millipore diffusion chambers containing spores alone or spores plus leucocytes into the peritoneal cavity of guinea-pigs further supported this concept (Suzuki, Booth, Benedik and Grecz, 1971). Ten per cent. of the animals given chambers containing spores alone died with typical symptoms of botulism, whereas chambers containing spores plus leucocytes killed 90 per cent. of the test guinea-pigs. Passively immunised guinea-pigs were able to survive the implantation of chambers containing $\mathrm{Cl}$. botulinum spores plus leucocytes. Thus, it has been established that polymorphonuclear (PMN) leucocytes can provoke a pathogenic state when interacting with $\mathrm{Cl}$. botulinum spores.

During phagocytic engulfment, lactic acid accumulates as a result of glycolysis and causes a rapid decrease in $p \mathrm{H}$ of the phagocytic vacuole $(\mathrm{Cohn}, 1968)$ to values as low as $p \mathrm{H} 3 \cdot 0-4 \cdot 5$ (Rous, 1925; Rowley, 1962). The pentose phosphate pathway present in peripheral leucocytes (Bona, Macovschi and Gheordunescu, 1969; Morton, Moran and Stjernholm, 1969) generates its metabolic by-product $\mathrm{H}_{2} \mathrm{O}_{2}$ and brings the reaction of the phagocytic vacuole to near neutrality. Concurrently, lysosome degranulation proceeds and brings into the proximity of the phagocytic vacuole a multitude of enzymes that include lysozyme and myeloperoxidase; the latter forms an effective bactericidal complex with $\mathrm{H}_{2} \mathrm{O}_{2}$ (Klebanoff, 1968, 1970; Paul et al., 1970).

The purpose of the present study was to determine the relationship of metabolic processes within the PMN leucocyte to the induction of intracellular $\mathrm{Cl}$. botulinum spore germination and subsequent toxin release.

Received 9 Oct. 1971; accepted 7 Feb. 1972.

* Present address: Dept of Pathology, St Luke's Hospital Center, Amsterdam at 114th St, New York, N.Y. 10025, USA.

J. MED. MICROBIOL.-VOL. 5 (1972) 


\section{MATERIALS AND METHODS}

Culture methods. A culture of Clostridium botulinum type A, strain 33A was grown at $30^{\circ} \mathrm{C}$ in 5 per cent. trypticase (Baltimore Biological Labs, Baltimore, Md), 0.5 per cent. peptone (Difco, Detroit, Mich.), $0 \cdot 1$ per cent. sodium thioglycollate and $20 \mu \mathrm{Ci}$ per litre of ${ }^{45} \mathrm{Ca}$ (International Chemical and Nuclear Corp., Irvine, Calif.). After 5-6 days, the radioactively labelled spores were harvested by centrifugation in a Sorvall RC-2 continuous flow centrifuge, and vegetative contaminants cleaned with trypsin and lysozyme as previously described (Grecz, Anellis and Schneider, 1962). This treatment does not affect spore resistance. ${ }^{45} \mathrm{Ca}$-labelled spores were stored in 0.85 per cent. $\mathrm{NaCl}$ in water at $2^{\circ}-4^{\circ} \mathrm{C}$.

Germination of bacterial spores was ascertained by observing the release of $\mathrm{Ca}$ (Powell and Strange, 1953) in the form of ${ }^{45} \mathrm{Ca}$ as described by Suzuki, Booth and Grecz (1971b).

Leucocytes. Venous blood samples from three healthy male donors and two patients with chronic granulomatous disease (CGD) were separately held in $30 \times 115 \mathrm{~mm}$ Falcon plastic centrifuge tubes (Falcon Plastics, Oxnard, Calif.) containing heparin 10 units per $\mathrm{ml}$ in 20 per cent. clinical dextran in saline solution (Travenol, Morton Grove, Ill.) and allowed to stand at room temperature for $45 \mathrm{~min}$. Dextran promotes sedimentation of erythrocytes by increasing rouleau formation.

The supernatant plasma containing leucocytes, platelets and some erythrocytes was withdrawn with a pasteur pipette and centrifuged at $50 \times g$ for $10 \mathrm{~min}$. The cell-free plasma was decanted and the leucocyte pellet washed with heparinised ( 1 unit per ml) Hanks' balanced salt solution at $p \mathrm{H} \mathrm{7.4} \mathrm{(HBSS,} \mathrm{Grand} \mathrm{Island} \mathrm{Biol.} \mathrm{Co.,} \mathrm{Grand} \mathrm{Island,} \mathrm{N.Y.)} \mathrm{and}$ resuspended in a known volume. PMN leucocytes and monocytes were counted in a haemocytometer, but small lymphocytes were omitted from the count; thus, cell counts refer to actual numbers of phagocytic cells. Lymphocytes were present but usually represented less than 20 per cent. of total numbers of cells. After another centrifugation, the cells were resuspended to a final concentration of $2 \times 10^{7}$ cells per $\mathrm{ml}$ in calcium-free HBSS with 30 per cent. fresh human adult serum.

Phagocytic index. Phagocytic indices were determined by the radioisotope method of Suzuki et al. (1971a) and expressed as percentages of total labelled spores engulfed.

\section{Phagocytosis systems with metabolic inhibitors}

All in-vitro incubations were carried out at $37^{\circ} \mathrm{C}$ in a shaking waterbath. Siliconised, sterile, Falcon plastic centrifuge tubes were used. Human PMN leucocytes and ${ }^{45} \mathrm{Ca}-$ labelled spores of $\mathrm{Cl}$. botulinum type A were added to HBSS with 30 per cent. human adult serum (Animal Blood Center, Syracuse, N.Y.) to give final concentrations of leucocytes at $10^{7}$ per $\mathrm{ml}$ and spores at $10^{8}$ per $\mathrm{ml}$. Control suspensions were then compared with leucocytespore suspension to which the following inhibitors were separately added: Glyceraldehyde (final concentration of $8 \mathrm{~mm}$ ) was added to the first test-tube concurrent with the addition of ${ }^{45} \mathrm{Ca}$-labelled spores to inhibit leucocytic glycolysis and, ultimately, phagocytosis (Selvaraj and Sbarra, 1966). Colchicine $(0.04 \mathrm{~mm})$ was introduced to a second leucocyte-spore suspension. This drug does not impair engulfment processes, but it interferes with leucocyte lysosomal degranulation during phagocytosis (Malawista and Bodel, 1967). The antithyroid agent, methimazole (1-methyl-2-mercapto imidazole), which inhibits thyroidal iodination, was found to inhibit the iodination reaction in leucocytes (Klebanoff and White, 1969). Accordingly, methimazole at a final concentration of $0.5 \mathrm{~mm}$ was added to a third leucocyte-spore suspension and incubated at $37^{\circ} \mathrm{C}$. At the concentration employed, methimazole had no effect on the phagocytosis of micro-organisms as determined by enumeration of intracellular bacteria in stained smears (Klebanoff and White). Azide also has no effect on phagocytosis or microbicidal activity at $0.1 \mathrm{~mm}$ (Klebanoff, 1970), and this was tested in a fourth leucocyte-spore suspension. Azide forms complexes with the iron of haem-containing enzymes such as myeloperoxidase, and therefore inhibits these enzymes. To a fifth in-vitro phagocytic system, methimazole and azide were added simultaneously at the concentrations 
employed above, thereby effecting a metabolic block at both the iodination and myeloperoxidase sites. A sixth leucocyte system was exposed to hydrocortisone $(0.21 \mathrm{~mm})$. Hydrocortisone selectively inhibits NADPH oxidase and therefore causes a lack of $\mathrm{H}_{2} \mathrm{O}_{2}$ production (Mandell, Ruben and Hook, 1970). The site of action of these metabolic inhibitors is summarised in the figure.

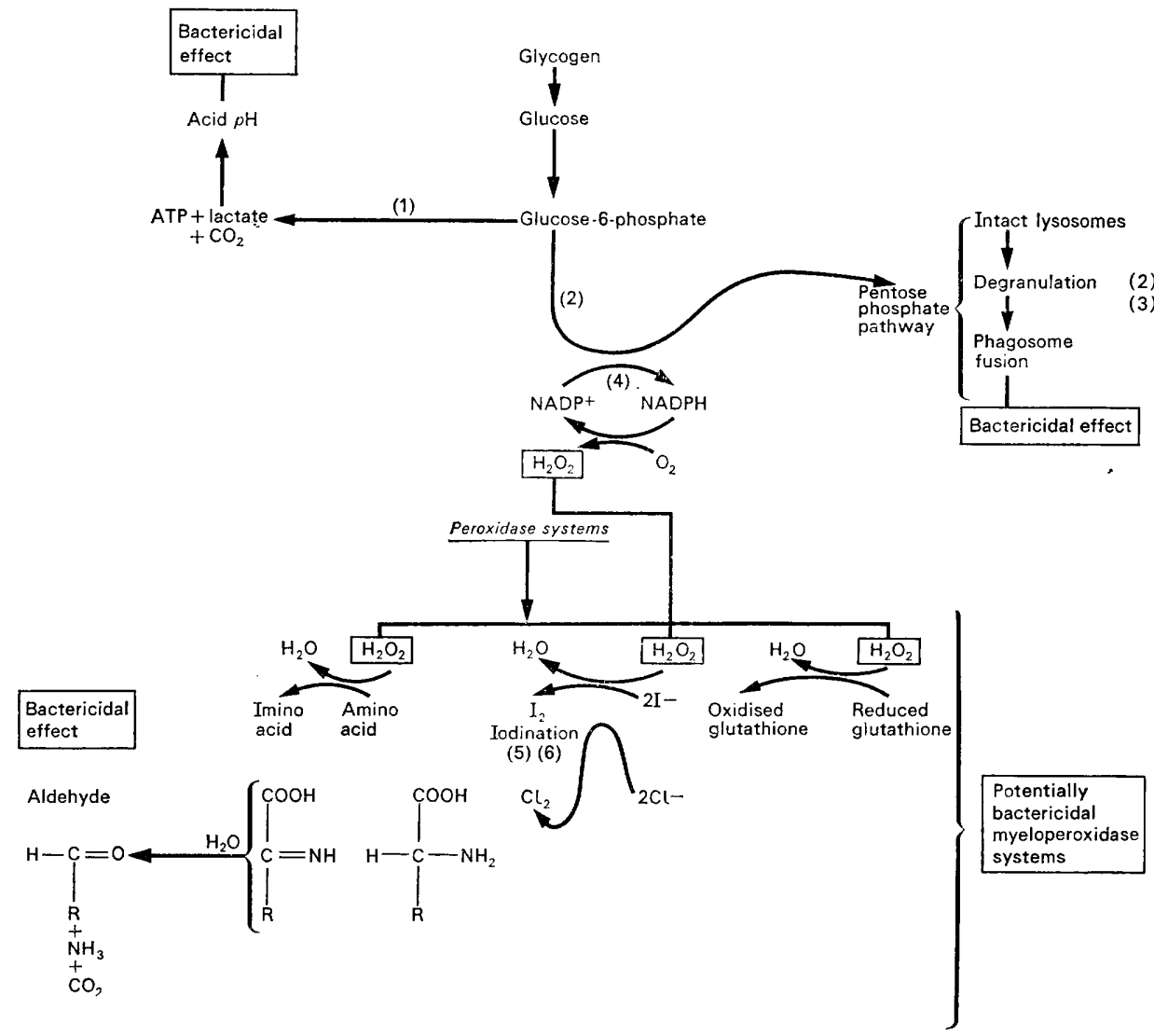

FIGURE.-Known metabolic pathways and physiological processes in the leucocyte during phagocytosis.

The numbers refer to the following metabolic inhibitors or genetic blocks that interfere with normal phagocyte function at the sites indicated: (1) glyceraldehyde, (2) chronic granulomatous disease, (3) colchicine, (4) hydrocortisone, (5) methimazole, (6) azide.

At specific time intervals $(0,1,2,4,6,8,12,24$ and $48 \mathrm{hr}), 1 \cdot 2$-ml volumes of each test mixture were filtered through a Millipore Swinney device equipped with a $0 \cdot 22 \mu \mathrm{m}$ filter. A 0.2-ml sample of this filtrate was placed in a glass scintillation vial with $10 \mathrm{ml}$ Bray's solution (Bray, 1960) and radioactivity was measured in a Beckman LS-200 Liquid Scintillation Counter at $14^{\circ} \mathrm{C}$ for $10 \mathrm{~min}$. The remainder of the filtrate $(1 \mathrm{ml})$ was injected IP into two mice to assay for botulinal toxin; one of the two mice passively immunised with type-A botulinal antitoxin served as a control for this assay.

\section{Phagocytosis system with chronic granulomatous disease cells}

One $\mathrm{ml}$ of prepared leucocytes $\left(2 \times 10^{7}\right.$ cells per $\left.\mathrm{ml}\right)$ derived from patients with CGD and $1 \mathrm{ml}$ of ${ }^{45} \mathrm{Ca}$-labelled $\mathrm{Cl}$. botulinum spores $\left(2 \times 10^{8}\right.$ per $\left.\mathrm{ml}\right)$ were mixed in siliconised test-tubes 
and placed in a shaking waterbath at $37^{\circ} \mathrm{C}$. Control mixtures contained prepared normal leucocytes at the same concentration. At $0,1,2,4,8,12,18,24,36$ and $48 \mathrm{hr}, 0 \cdot 2-\mathrm{ml}$ vols were filtered through a Millipore Swinney device equipped with a $0.22 \mu \mathrm{m}$ filter. The filtrate was placed in a glass scintillation vial, and radioactivity was determined as above.

TABLE I

Release of free ${ }^{45} \mathrm{Ca}$ from labelled spores of Clostridium botulinum type $33 \mathrm{~A}$ in leucocyte cultures as an index of intracellular spore germination in the presence of various leucocyte inhibitors at $37^{\circ} \mathrm{C}$

\begin{tabular}{|c|c|c|c|c|c|c|c|c|c|}
\hline \multirow{2}{*}{ Inhibitor added } & \multicolumn{9}{|c|}{$\begin{array}{l}\text { Relative amount of free }{ }^{45} \mathrm{Ca} \text { released* (counts per min.) from unit } \\
\text { volumes of leucocyte-spore mixtures at the stated time (hr) of incubation }\end{array}$} \\
\hline & 0 & 2 & 4 & 8 & 12 & 18 & 24 & 36 & 48 \\
\hline $\begin{array}{l}\text { Control } \\
\text { (no inhibitor added) }\end{array}$ & 81 & 84 & 89 & 203 & 430 & 1253 & 1509 & 1537 & 1626 \\
\hline $\begin{array}{l}\text { Glyceraldehyde } \\
\text { Colchicine } \\
\text { Methimazole } \\
\text { Azide } \\
\text { Azide+ methimazole } \\
\text { Hydrocortisone }\end{array}$ & $\begin{array}{l}83 \\
78 \\
69 \\
71 \\
79 \\
84\end{array}$ & $\begin{array}{l}85 \\
82 \\
73 \\
74 \\
79 \\
89\end{array}$ & $\begin{array}{l}91 \\
90 \\
83 \\
90 \\
91 \\
94\end{array}$ & $\begin{array}{r}91 \\
103 \\
191 \\
188 \\
192 \\
207\end{array}$ & $\begin{array}{l}103 \\
142 \\
403 \\
381 \\
392 \\
419\end{array}$ & $\begin{array}{r}110 \\
194 \\
1201 \\
1222 \\
1241 \\
1243\end{array}$ & $\begin{array}{r}132 \\
281 \\
1489 \\
1461 \\
1496 \\
1519\end{array}$ & $\begin{array}{r}183 \\
314 \\
1530 \\
1529 \\
1526 \\
1530\end{array}$ & $\begin{array}{r}210 \\
371 \\
1588 \\
1597 \\
1584 \\
1629\end{array}$ \\
\hline $\begin{array}{l}\text { Cell-free leucocyte } \\
\text { extract with spores }\end{array}$ & 80 & 81 & 83 & 84 & 87 & 94 & 98 & 103 & 143 \\
\hline
\end{tabular}

* Free ${ }^{45} \mathrm{Ca}$ determined by counting $0 \cdot 22 \mu \mathrm{m}$ Millipore filtrate of in-vitro leucocyte-Cl. botulinum spore systems. Average of three experiments $(P=0.05)$. Background count has been subtracted in each case.

\section{RESULTS}

In the control suspension of $45 \mathrm{Ca}$-labelled $\mathrm{Cl}$. botulinum spores and leucocytes incubated in vitro, ${ }^{45} \mathrm{Ca}$ release representing spore germination occurred

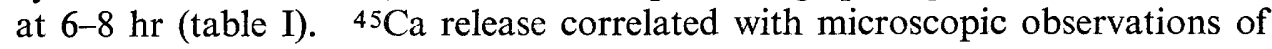
spore phase-darkening.

The data given in table $I$ indicate that, in the presence of glyceraldehyde or colchicine, ${ }^{45} \mathrm{Ca}$ release was substantially inhibited. Spore germination was depressed to a greater extent with glyceraldehyde than with colchicine. This observation suggests that glycolysis-dependent leucocyte engulfment is the predominant factor in this type of spore germination. However, neither methimazole $(0.5 \mathrm{~mm})$ nor azide $(0.1 \mathrm{~mm})$, both known inhibitors of the iodinemyeloperoxidase bactericidal system of Klebanoff (1968), significantly affected leucocyte-induced spore germination. Even in combination, azide+methimazole had negligible effects. Phagocytic indices of all leucocyte-spore in-vitro systems containing colchicine, methimazole, azide or hydrocortisone at the stated concentrations were not depressed; this indicates that there was no interference with engulfment. Glyceraldehyde depressed the phagocytic index by 53 per cent.; since glyceraldehyde blocks glycolysis, the metabolic 
pathway responsible for phagocytic engulfment, the observed depression is consistent with the findings of Selvaraj and Sbarra. Hydrocortisone, which selectively inhibits NADPH oxidase (Mandell et al., 1970)-the enzyme responsible for generation of $\mathrm{H}_{2} \mathrm{O}_{2}$ in the leucocyte-was found to have no effect on intraleucocytic $\mathrm{Cl}$. botulinum spore germination.

Germination of ${ }^{45} \mathrm{Ca}$-labelled spores of the test strain $\mathrm{Cl}$. botulinum $33 \mathrm{~A}$ in trypticase-peptone broth was studied by determining the release of free ${ }^{45} \mathrm{Ca}$. Spores in the bacteriological culture medium to which glyceraldehyde,

TABLE II

Release of toxin from $\mathrm{Cl}$. botulinum spores ingested by polymorphonuclear leucocytes and the influence of various inhibitors on toxin release during incubation at $37^{\circ} \mathrm{C}$

\begin{tabular}{l|c|c}
\hline \multicolumn{1}{c|}{ Inhibitor added } & $\begin{array}{c}\text { Number of mice killed* by challenge with filtrate } \\
\text { taken during the stated incubation period }\end{array}$ \\
\cline { 2 - 3 } & $0-4 \mathrm{hr}$ & $6-48 \mathrm{hr}$ \\
\hline Control (no inhibitor added) & 0 & 5 \\
Glyceraldehyde & 0 & 0 \\
Colchicine & 0 & 0 \\
Methimazole & 0 & 5 \\
Azide & 0 & 5 \\
Methimazole + azide & 0 & 5 \\
Hydrocortisone & 0 & 5 \\
\hline
\end{tabular}

* Total of five mice challenged per experiment at each of the following time intervals: $0,2,4,6$, $8,12,24$ and $48 \mathrm{hr}$. A dose of $1 \mathrm{ml}$ of filtrate was injected intraperitoneally. Control mice immunised with botulinal type A antitoxin survived.

colchicine, methimazole, azide or methimazole plus azide was added at the test concentration showed normal germination patterns compared with control suspensions in the medium alone.

The results summarised in table II suggest that phagocytosis was required for release of $\mathrm{Cl}$. botulinum toxin from spores. When $\mathrm{Cl}$. botulinum spores are incubated with leucocytes without chemical inhibitors, botulinal toxin began to be demonstrable in filtrates at $6 \mathrm{hr}$. However, no toxin was demonstrable when glyceraldehyde or colchicine was present in the test mixtures. Neither methimazole nor azide inhibited release of toxin; when the two inhibitors were used simultaneously, there was still little effect on release of free ${ }^{45} \mathrm{Ca}$ or botulinal toxin.

At $24 \mathrm{hr}$, trypan blue dye exclusion staining indicated that only 25 per cent. leucocyte viability was lost when treated with metabolic inhibitors and the loss of viability in control non-treated leucocytes averaged 20 per cent.

In table III the capacity to initiate germination by leucocytes derived from a normal patient is compared with that of leucocytes from two different CGD patients (T. W. and M. S.). Although CGD leucocytes can induce some germination, they are clearly defective in this regard. This defect is evident at 
$8 \mathrm{hr}$ and pronounced by $12-18 \mathrm{hr}$. The maximum release of $45 \mathrm{Ca}$ was less than half that of normal cells in both instances. The results for a patient's cells are compared with those obtained with normal cells tested on the same day.

\section{DISCUSSION}

The results of the present study concur with previous findings that spores of Clostridium botulinum are capable of germination after phagocytosis by polymorphonuclear (PMN) leucocytes (Suzuki, Booth and Grecz, 1970; Booth,

TABLE III

Release of free ${ }^{45} \mathrm{Ca}$ from labelled spores of $\mathrm{Cl}$. botulinum $33 \mathrm{~A}$ ingested by normal and chronic granulomatous disease polymorphonuclear leucocytes as an index of spore germination

\begin{tabular}{|c|c|c|c|c|c|c|c|c|c|}
\hline \multirow{2}{*}{ Test material } & \multicolumn{9}{|c|}{$\begin{array}{l}\text { Relative amount of free }{ }^{45} \mathrm{Ca} \text { released* (counts per minute) from unit } \\
\text { volumes of leucocyte-spore mixtures or leucocyte extract-spore mixtures } \\
\text { at the stated time (hr) of incubation }\end{array}$} \\
\hline & 0 & 2 & 4 & 8 & 12 & 18 & 24 & 36 & 48 \\
\hline $\begin{array}{l}\text { Normal } \\
\text { leucocytes }\end{array}$ & 94 & 96 & 100 & 108 & 268 & 1198 & 1412 & 1483 & 1496 \\
\hline $\begin{array}{c}\text { CGD } \dagger-T \text { T. W. } \\
\text { leucocytes }\end{array}$ & 97 & 99 & 101 & 103 & 124 & 589 & 590 & 691 & 760 \\
\hline $\begin{array}{l}\text { CGD-M. S. } \\
\text { leucocytes }\end{array}$ & 96 & 96 & 99 & 104 & 133 & 604 & 710 & 753 & 773 \\
\hline $\begin{array}{l}\text { Cell-free leucocyte } \\
\text { extract }\end{array}$ & 80 & 81 & 83 & 84 & 87 & 94 & 98 & 103 & 143 \\
\hline
\end{tabular}

* Free ${ }^{45} \mathrm{Ca}$ determined by counting $0.22 \mu \mathrm{m}$ Millipore filtrates from in-vitro leucocyte-spore systems. Average of three experiments $(P=0 \cdot 05)$. Background count has been subtracted in each case.

$\dagger$ Chronic granulomatous disease.

$\ddagger$ T. W. and M.S. are the initials of the CGD patients.

Suzuki and Grecz, 1971a). The inhibitors used in the present study did not prevent spore germination per se. This was not unexpected since many of the metabolic inhibitors normally used in leucocyte function tests are not inhibitory to spore germination (Wynne, 1957; Murrell, 1961). Spores of Cl. botulinum strain 33A did not proceed to outgrowth when held in Krebs-Ringer phosphate medium +leucocyte extracts + serum at $p \mathrm{H} 7 \cdot 4$ (Suzuki, Booth and Grecz, 1970).

The data clearly demonstrate that normal physiological functions within the leucocyte, particularly glycolysis and the pentose-phosphate pathway, are involved in triggering the germination of engulfed spores. It is interesting that methimazole and azide were found not to affect leucocyte-induced germination or release of toxin from $\mathrm{Cl}$. botulinum spores. Methimazole and azide are known to be selective inhibitors respectively of iodination (Klebanoff and White, 1969) and myeloperoxidase (Klebanoff, 1970), two important bactericidal mechanisms of the leucocyte. These apparently paradoxical results may be explained by the observation that the act of cell killing, i.e., bactericidal 
action, which is influenced by methimazole and azide, is immaterial with respect to spore germination because: (i) mature spores are extremely resistant to direct chemical attack such as that found in the leucocytes; (ii) spore germination is not necessarily linked to spore viability (spores killed by radiation are still phase-bright and refractile to stains); and (iii) after germination within the leucocyte, the germinated spores are destroyed by lytic processes that are independent of iodination and myeloperoxidase.

Hydrocortisone blocks the enzyme NADPH oxidase requisite for $\mathrm{H}_{2} \mathrm{O}_{2}$ production and lysosome degranulation. Evidently $\mathrm{H}_{2} \mathrm{O}_{2}$ does not play a major role in leucocyte-induced spore germination or toxin release since hydrocortisone did not significantly inhibit spore germination.

The relationship of leucocyte metabolism to changes in the ingested $\mathrm{Cl}$. botulinum spore was further evaluated in our studies with the genetically defective leucocytes found in patients with chronic granulomatous disease of childhood (see Good et al., 1968). CGD cells engulf normally, but intracellular events are defective: there is a profound depression of the pentose pathway and, in addition, the burst of oxygen consumption and production of $\mathrm{H}_{2} \mathrm{O}_{2}$ that normally occurs in association with phagocytic uptake is greatly reduced (Holmes, Page and Good, 1967).

Phagocytic leucocytes from two male patients with chronic granulomatous disease were found to be greatly reduced in their capacity to induce $\mathrm{Cl}$. botulinum type A spore germination. It is postulated that this reflects the basic genetic defect in CGD leucocytes and that optimum intracellular germination of Cl. botulinum spores in normal leucocytes requires metabolic events or substances that are defective or lacking in CGD cells. Evidently CGD leucocytes engulf normally. Phagocytic engulfment has been correlated with a normal glycolytic pathway in such cells (Holmes et al., 1967). Thus, even though germination of $\mathrm{Cl}$. botulinum spores was decreased in normal leucocytes in the presence of inhibitors of glycolysis, it is reasonable to state that glycolysis alone does not induce germination. The role of the glycolytic pathway is to provide metabolism necessary for phagocytic uptake; intracellular action upon the engulfed material depends on other processes, some of which may be defective in CGD cells (i.e., $\mathrm{H}_{2} \mathrm{O}_{2}$ production, lysosome degranulation).

Gould and Hitchins (1963) presented evidence that $\mathrm{H}_{2} \mathrm{O}_{2}$ could cause changes in spores of Bacillus and Clostridium species with resultant phasedarkening and loss of dipicolinic acid typical of normal germination. However, this occurred only if the spores were previously treated in a manner known to rupture protein disulphide bonds. Similar pretreatment was required to make such spores susceptible to lysozyme. Hydrogen peroxide, on the other hand, seemed to cause progressive spore lysis in addition to the germinative changes. The authors postulated that disulphide bond rupture in spore coats permitted the action of lysozyme or $\mathrm{H}_{2} \mathrm{O}_{2}$ on previously protected substrates with consequent germination.

Exposure of spores to acidic $p \mathrm{H}$ within phagocytic vacuoles could possibly alter protein disulphide bonds enough to allow lytic enzyme molecules, such as lysozyme, to pass through to the underlying susceptible layers. Toxin release 
could possibly then be effected by continual action of lysozyme on the germinated spore or the bacterial cell wall of the outgrowing cell.

The depressed spore germination in the CGD leucocyte system may be attributed to a defect in the $\mathrm{H}_{2} \mathrm{O}_{2}$-generating system of CGD cells. However, it must be noted that the CGD leucocytes contain normal amounts of lysozyme (Quie et al., 1967) and that hydrocortisone-treatment of leucocytes whereby $\mathrm{H}_{2} \mathrm{O}_{2}$ production is blocked, did not inhibit germination of the ingested spores.

It is possible then that, in regard to phagocytic activity in the CGD leucocyte, lysosomes may not completely degranulate or fuse with phagocytic vacuoles, thereby providing decreased amounts of lysozyme in the phagocytic vacuole. This would explain a depressed but not totally inhibited induction of spore germination. Although Quie et al. contended that lysosomal degranulation is completely absent in CGD cells, others (Holmes et al., 1967; Kauder et al., 1968; Baehner, Karnovsky and Karnovsky, 1969) have demonstrated that this may not be the case. With a CGD defect in lysosomal degranulation, spore germination would be depressed-provided that the lysosomal enzyme, lysozyme, is required for leucocyte-induced spore germination. If lysozyme is responsible for induction of germination, as suggested by the present results, small amounts of the enzyme must be available to engulfed spores enclosed in the phagocytic vacuole. Partial degranulation of lysosomes would account for the observed, although decreased, liberation of ${ }^{45} \mathrm{Ca}$ from labelled spores.

The present results suggest that digestive processes occurring during normal phagocytosis, i.e., glycolysis resulting in acidic $\mathrm{pH}$ and the action of lysosomal enzymes (e.g., lysozyme), seem to create conditions conducive to spore germination. It is possible that this action is a general one for many types of bacterial spores and that elucidation of this process may shed further light on some hostparasite interactions.

\section{SUMMARY}

The environment within the metabolically active polymorphonuclear leucocyte during phagocytosis is conducive to the germination of phagocytically ingested spores of Clostridium botulinum type A. Specific metabolic inhibitors of leucocyte function-glyceraldehyde, hydrocortisone, colchicine, methimazole and azide-were used to study metabolic pathways during phagocytosis that may be responsible for inducing spore germination within the leucocyte.

Leakage of ${ }^{45} \mathrm{Ca}$ from labelled $\mathrm{Cl}$. botulinum spores was taken as evidence of spore germination. Release of free ${ }^{45} \mathrm{Ca}$ from phagocytosed spores in sporeleucocyte mixtures in in-vitro systems was normal in the presence of hydrocortisone, methimazole, azide and methimazole +azide. These findings indicate that $\mathrm{H}_{2} \mathrm{O}_{2}$ production, iodination and myeloperoxidase activities during phagocytosis are not required for germination. In the presence of glyceraldehyde or colchicine, release of ${ }^{45} \mathrm{Ca}$ from spore-leucocyte mixtures was profoundly inhibited and this indicates that glycolysis and lysosome degranulation are essential for intraleucocytic spore germination. 
In leucocytes from patients with a genetic abnormality of phagocytosis, i.e., chronic granulomatous disease of childhood (CGD), germination of spores was significantly depressed. Since normal mechanisms of $\mathrm{H}_{2} \mathrm{O}_{2}$ production and possibly of lysosomal degranulation are blocked in CGD leucocytes, the results suggest that $\mathrm{H}_{2} \mathrm{O}_{2}$ and lysosomal enzymes are involved in triggering spore germination in this model. Nevertheless, a limited release of $45 \mathrm{Ca}$ was observed and this seems to indicate that small amounts of lysosomal enzymes are available for reaction with engulfed spores in CGD leucocytes.

The results of these studies with metabolic inhibitors and genetic blocks lead to the view that germination of spores of $\mathrm{Cl}$. botulinum within leucocytes is triggered by the combined action of lowered $p \mathrm{H}$ resulting from glycolysis together with lytic enzymes resulting from degranulation of lysosomes.

The assistance of Dr Dorothy Windhorst of the University of Chicago School of Medicine and of Andrew Benedik of Chicago Osteopathic Medical School are greatly appreciated. This investigation was supported by Public Health Service Grant FD-00358 from the Food and Drug Administration, Consumer Protection and Environmental Health Service.

\section{REFERENCES}

Baehner, R. L., Karnovsky, M. J., AND KarnovSKy, M. L. 1969. Degranulation of leukocytes in chronic granulomatous disease. J. Clin. Invest., 48, 187.

Booth, R., Suzuki, J. B., AND GreCz, N. 1971a. Pathogenesis of Clostridium botulinum spores: in vivo fate of C. botulinum type A spores. Trans. Ill. State Acad. Sci., 64, 147.

Booth, R., Suzuki, J. B., AND Grecz, N.1971b. Sequential use of Wright's and Ziehl-Neelsen's stains in demonstrating phagocytosis of bacterial spores. Stain Technol., 46, 23.

Bona, C., Macovschi, O., AND Gheordunescu, V. 1969. Dehydrogenase and oxidase activities of guinea pig leukocytes during pinocytosis. J. Reticuloendothel. Soc., 6, 271.

BrAY, G. A. 1960. A simple efficient liquid scintillator for counting aqueous solution in a liquid scintillation counter. Analyt. Biochem., 1, 279.

CoHN, Z. A. 1968. The structure and function of monocytes and macrophages. $A d v$. Immun., 7, 163.

Good, R. A., Quie, P. G., Windhorst, D. B., Page, A. R., Rodey, G. E., White, J., Wolfson, J. J., AND Holmes, B. H. 1968. Fatal (chronic) granulomatous disease of childhood: a hereditary defect of leukocyte function. Semin. Hematol., 5, 215.

Gould, G. W., AND Hitchins, A. D. 1963. Sensitization of bacterial spores to lysozyme and to hydrogen peroxide with agents which rupture disulphide bonds. J. Gen. Microbiol., 33, 413.

Grecz, N., Anellis, A., AND Schneider, M. D. 1962. Procedure for cleaning of Clostridium botulinum spores. J. Bact., 84, 552.

Holmes, B., Page, A. R., AND Good, R. A. 1967. Studies of the metabolic activity of leukocytes from patients with a genetic abnormality of phagocytic function. J. Clin. Invest., 46, 1422.

Kauder, E., Kahle, L. L., Moreno, H., and Partin, J. C. 1968. Leukocyte degranulation and vacuole formation in patients with chronic granulomatous disease of childhood. J. Clin. Invest., 47, 1753.

KLEBANOFF, S. J. 1968. Myeloperoxidase-halide-hydrogen peroxide antibacterial system. J. Bact., 95, 2131.

KLebanoff, S. J. 1970. Myeloperoxidase: contribution to the microbicidal activity of intact leukocytes. Science, N.Y., 169, 1095.

Klebanoff, S. J., AND White, L. R. 1969. Iodination defect in the leukocytes of a patient with chronic granulomatous disease of childhood. New Engl. J. Med., 280, 460. 
Malawista, S. E., and Bodel, Phyllis T. 1967. The dissociation by colchicine of phagocytosis from increased oxygen consumption in human leukocytes. J. Clin. Invest., 46, 786.

Mandell, G. L., Rubin, W., AND Hook, E. W. 1970. The effect of an NADH oxidase inhibitor (hydrocortisone) on polymorphonuclear leukocyte bactericidal activity. $J$. Clin. Invest., 49, 1381.

Morton, D. J., Moran, J. F., ANd StJernholm, R. L. 1969. Carbohydrate metabolism in leukocytes. XI. Stimulation of eosinophils and neutrophils. J. Reticuloendothel. Soc., 6, 525 .

MURRell, W. G. 1961. Spore formation and germination as a microbial reaction to the environment. Symp. Soc. Gen. Microbiol., 11, 100.

Paul, B. B., Strauss, R. R., Jacobs, A. A., and Sbarra, A. J. 1970. Function of $\mathrm{H}_{2} \mathrm{O}_{2}$, myeloperoxidase, and hexose monophosphate shunt enzymes in phagocytizing cells from different species. Infect. Immun., 1, 338.

Powell, Joan F., and Strange, R. E. 1953. Biochemical changes occurring during the germination of bacterial spores. Biochem. J., 54, 205.

QuIE, P. G., White, J. G., Holmes, B., AND Good, R. A. 1967. In vitro bactericidal capacity of human polymorphonuclear leukocytes: diminished activity in chronic granulomatous disease of childhood. J. Clin. Invest., 46, 668.

Rous, P. 1925. The relative reaction within living mammalian tissues. II. On the mobilization of acid material within cells, and the reaction as influenced by the cell state. J. Exp. Med., 41, 399.

Rowley, D. 1962. Phagocytosis. Adv. Immun., 2, 241.

Selvaraj, R. J., and Sbarra, A. J. 1966. Relationship of glycolytic and oxidative metabolism to particle entry and destruction in phagocytosing cells. Nature, Lond., 211, 1272.

SuzukI, J. B., Booth, R., AND GreCz, N. 1970. Pathogenesis of Clostridium botulinum type A: release of toxin from C. botulinum spores in vitro by leukocytes. Res. Commun. Chem. Path. Pharmac., 1, 691.

SuzUKI, J. B., BoOTH, R. R., AND GRECZ, N. 1971a. Evaluation of phagocytic activity by ingestion of labelled bacteria. J. Infect. Dis., 123, 93.

SuzukI, J. B., Booth, R. R., AND GRECZ, N. 1971b. In-vivo and in-vitro release of $\mathrm{Ca}^{45}$ from spores of Clostridium botulinum type $\mathrm{A}$ as further evidence for spore germination. Res. Commun. Chem. Path. Pharmac., 2, 16.

Suzuki, J. B., Booth, R., Benedik, A., ANd Grecz, N. 1971. Pathogenesis of Clostridium botulinum type A: study of in vivo toxin release by implantation of diffusion chambers containing spores, vegetative cells and free toxin. Infect. Immun., 3, 659.

WYNNE, E. S. 1957. Symposium on bacterial spore germination. Bact. Rev., 21, 259. 